\title{
CONSEQUENCES OF THE USE OF PERSONALIZATION ALGORITHMS IN SHAPING AN OFFER - A PRIVATE LAW PERSPECTIVE*
}

by

KATARZYNA POŁUDNIAK-GIERZ

Personalization mechanisms in consumer e-commerce allow for the adjustment of the time, form and manner of contact, the way of concluding the contract and the availability and content of the offer. Subsequently concluded agreements can be seen as a new phase of development of the consumer transaction model - secondary individualization replaces standardization. The possibility of concluding contracts on a massive scale is retained, but with added granularity and flexibility that mimic the individualisation of transactions. Special provisions for personalized contracts are missing on the EU level and within the Polish legal system.

The starting point is an analysis of the reaction of the traditional private instruments of Polish law towards the personalization of offers - case law and doctrinal approach towards the concept of a standard contract and an individually negotiated one are examined. Next, the pre-contractual stage is investigatedthe personalization process is explored from the perspective of unfair practices regulation, and the legal basis for the personalization process in the context of the GDPR is discussed. While Polish national law focuses on combating the undesired results of personalization, the EU initiatives aim at granting ex-ante protection. The mechanism in directive 2005/29/EC is being supplemented with an information protection mechanism (consent requirement). The limitations of this model are identified and some alternative solutions are proposed.

The following paper is a part of the research conducted within the framework of the project no. 2016/21/N/HS5/00167 Personalized agreements in the light of civil law grant-financed by the National Science Centre of Poland.

** katarzyna.poludniak@uj.edu.pl, PhD Candidate at the Department of Civil Law, Jagiellonian University in Kraków, Poland. 


\section{KEY WORDS}

Consumer Protection, GDPR, Personalization, Unfair Commercial Practices

\section{INTRODUCTION}

An initial assumption of the study is that contracts concluded using personalization mechanisms ${ }^{1}$ are a new step in the development of consumer contracts. Private law emerged as an individualised system, giving its subjects broad autonomy in the contractual sphere. ${ }^{2}$ Since the beginning of mass production in the 19th century, the model of the individual contract has become obsolete. ${ }^{3}$ Individually negotiated contracts were replaced by unilaterally formulated standard contracts. ${ }^{4}$ The other party, as a rule being the weaker one, could either consent or resign from concluding a contract. $^{5}$ In response, the legislature introduced protective standards aimed at diminishing the undesired effects of the growing asymmetries in private relations. ${ }^{6}$

\footnotetext{
In the paper broad understanding of the term is adopted - it covers all the adjustments of the content that are perceived by the addressee as adopted individually for him, to match his personal needs. Personalization should not be confused with customization in case of which modification of standard content are introduced by the addressee himself.

2 Mularski, K. and Radwański, Z. (2019) Zagadnienia ogólne czynności prawnych. In: Zbigniew Radwański (ed.). System prawa prywatnego, 2, Zbigniew Radwański, Andrzej Olejniczak (eds.). Prawo cywilne - część ogólna. 3rd ed. Warszawa: C.H. Beck, pp. 7-8, 13.

3 Łętowska, E. (1974) Problematyka ogólnych warunków i wzorów umów w świetle poglądów doktryny obcej. Studia Prawnicze, 3, pp. 152-153; Bednarek, M. (2013) Wzorce umów. In: Zbigniew Radwański (ed.). System Prawa Prywatnego, 5, Ewa Łętowska (ed.). Prawo zobowiązań - czẹść ogólna. 2nd ed. Warszawa: C.H. Beck, pp. 604-605; Pyrzyńska, A. (2019) In: Kodeks cywilny. Tom II. Komentarz. Art. 353-626, Maciej Gutowski (ed.). 2nd ed. Warszawa: C.H. Beck, Art. 384, point I.1.

4 This notion used in Directive 93/13/EEC of 5 April 1993 on unfair terms in consumer contracts. Art. 384-385, 385 (4) of Polish Civil Code (Dz.U.2018.1025) refer to the same phenomenon under the notion of "a contract concluded with the use of standard terms". Polish legislator differentiates also contracts with unilaterally imposed provisions (art. 385 (1)-385 (3) PCC). Hondius, E. (1995) The Reception of Directive on Unfair Terms in Consumer Contracts by Member States. European Review of Private Law, 3, p. 245; Pyziak-Szafnicka, M. (1994) Kilka uwag na temat ochrony przed narzucaniem nieuczciwych warunków umowy. Przegląd Prawa Handlowego, 9, p. 1; Łętowska, E. (2004) Nieuczciwe klauzule w prawie umów konsumenckich. Warszawa: C. H. Beck, p. 2.

5 Łętowska, E. (1974) Op. cit., pp. 123-124; Bednarek, M. (2005) Wzorce umów w prawie polskim. Warszawa: Monografie Prawnicze, pp. 10-11; Mikłaszewicz, P. (2008) Obowiazki informacyjne w umowach z udziałem konsumentów na tle prawa Unii Europejskiej. Warszawa, Kraków: Wolters Kluwer Polska, pp. 211-216.

6 Twigg-Flesner, C. (2010) In: Hans-W. Micklitz, Jules Stuyck and Evelyne Terryn (eds.). Cases, materials and Text on Consumer Law. Oxford, Portland, Oregon: Hart Publishing, pp. 321-322; Schulze, R. and Zoll, F. (2018) European Contract Law. München: C. H. Beck; Oxford: Hart; Baden-Baden: Nomos, pp. 153-155; Zoll, F. (2018) Rẹkojmia. Odpowiedzialność sprzedawcy. Warszawa: Wydawnictwo C. H. Beck, Legalis, Chapter II § 1 point II; Hellwege, P. (2018) Right of Withdrawal in Distance and Off-Premises Contracts. In: Nils Jansen, Reinhard Zimmermann (eds.). Commentaries on European contract laws. Oxford: Oxford University Press, pp. 509, 511-513.
} 
Personalization technologies allow for the re-individualization of contracts. Contracts are designed by the entrepreneur to match the individual characteristics, preferences or situation of the consumer, which gives him the impression that his relationship with the entrepreneur is based on trust and knowledge - the personalized contract model emerges. The main research questions are if and is how does the legal system react towards the use of personalization algorithms in shaping offers?

To avoid presenting fragmentary, distorted analysis the paper is divided into three sections. In each one a regulatory framework with different methodology approach is discussed - can it be applied, what are the most problematic issues that emerge during its application and does it fulfil its aim in case of personalized agreements? The first regime (contract law provisions on standard contracts ${ }^{7}$ ) provides protection by intervening in the content of legal relationship - ex post, by modifying the final result of applying personalization techniques during pre-contractual stage. The second $\left[\right.$ norms $^{8}$ introduced to national private law as an implementation of Unfair Commercial Practices Directive (UCPD) $\left.{ }^{9}\right]$ grants protection by setting requirements around the process of personalization - it outlines rules on entrepreneurs' actions that lead to conclusion of personalized agreement. Within the last group of norms $\left(\mathrm{GDPR}^{10}\right)$ information based protection model is adopted - based on the assumption that individuals (usually consumers) are able to make a rational decision on consenting to personalization if they have access to relevant information. ${ }^{11}$ The possible effectiveness of these regimes is assessed - their weaknesses are identified and possible solution proposed.

\footnotetext{
Art. 384-3854 of PCC.

8 Act on Competition and Consumer Protection (Dz.U.2018.798 j.t.) and the Act on Counteracting Unfair Market Practices (Dz.U.2017.2070 j.t.).

9 Directive 2005/29/EC of 11 May 2005 concerning unfair business-to-consumer commercial practices in the internal market and amending Council Directive 84/450/EEC, Directives 97/7/EC, 98/27/EC and 2002/65/EC of the European Parliament and of the Council and Regulation (EC) No 2006/2004 of the European Parliament and of the Council. Official Journal of the European Union (2005/L 149/22).

10 Regulation (EU) 2016/679 of the European Parliament and of the Council of 27 April 2016 on the protection of natural persons with regard to the processing of personal data and on the free movement of such data, and repealing Directive 95/46/EC (General Data Protection Regulation). Official Journal of the European Union (L 119/1). Available from: http://data.europa.eu/eli/reg/2016/679/oj [Accessed 16 September 2019].

11 Busch, C. (2019) Implementing Personalized Law: Personalized Disclosures in Consumer Law and Data Privacy Law. The University of Chicago Law Review, 86 (2), p. 310.
} 


\section{PERSONALIZATION - BETWEEN A STANDARD AND AN INDIVIDUALLY NEGOTIATED CONTRACT}

The starting point of the analysis are the traditional private law instruments inherent for the core of national contract law [Polish Civil Code (PCC)], shaped under the influence the EU legislator in the last decade of 20th century. ${ }^{12}$ These norms allow for determination of the content of the contractual relationship (final result of personalization within consumer market). There are no provisions that explicitly regulate personalization. Such agreement has characteristics typical of an individually negotiated contract, a unilaterally imposed set of provisions and a standard contract. Each one of the aforementioned is governed by a different set of norms. Discrepancies appear in regard to inter alia rules of the incorporation of provisions, their interpretation and the legal reaction towards the lack of equivalency of those relations. ${ }^{13}$ Therefore, qualification of a personalized contract as a standard contract, a set of imposed provisions or an individually negotiated contract may significantly affect the position of the consumer in the contractual relationship. As a result, it is crucial to determine under which regime personalized contracts fall. Consequently, despite the fact that PCC does not recognise personalized agreements as a new model of contracting within consumer e-commerce, the use of personalization mechanisms cannot be disregarded at the stage of applying the law.

As a legal definition for a contract concluded with the use of standard terms is missing from the PCC, ${ }^{14}$ there have been numerous attempts to define these contracts in case law ${ }^{15}$ and doctrine. ${ }^{16}$ Definitions of standard terms are based on the quantitative premise (number of contracts

$\overline{12}$ Council Directive 93/13/EEC of 5 April 1993 on unfair terms in consumer contracts. Official Journal of the European Union (L 95/29). Available from: https://eur-lex.europa.eu/legalcontent/EN/TXT/?uri=CELEX\%3A31993L0013 [Accessed 16 September 2019].

13 Discrepancies appear in regard to: rules on whether behaviour of the parties can be seen as reaching consensus as to the inclusion of certain elements to the legal relationship, possibility of interpretation of the content of contract in accordance with legitimate expectations against the wording of the contract, requirements to successfully set the characteristics of the subject of contract as being below the standard quality, the binding power of provisions that shape rights and duties of one party in a manner contrary to good practices with gross violation of his interests.

14 Rejdak, M. (2005) Definicja terminu „wzorzec umowy konsumenckiej”. Ruch Prawny, Ekonomiczny i Socjologiczny, LXVII (3), p. 116.

15 Judgement of Constitutional Tribunal (8.12.2003), K 3/02, OTK-A 2003/9/99; judgements of Polish Supreme Court: (5.09.1991) III CZP 75/91, OSNC 1992/5/ 67; (7.07.2005) V CK 855/04, PUG 2005/10, p. 33; (26.03.2010) I CSK 444/09 Legalis no 362191; (20.07.2017) I CSK 704/16, Legalis no 1668805; (1.03.2017), IV CSK 285/16, LEX no 2308321. 
concluded) or the objective premise (normative provisions regarding the scope of business or professional activity of the entrepreneur). Yet, these distinction prove to be unsuitable when assessing whether a personalized contract may constitute a standard one. It is reasonable to use descriptive definitions based on the enumeration of the standard terms features.

Standard terms in Polish law are (2.1.) a set of provisions prepared unilaterally by one party (2.2.) used for mass contracting (2.3) which shapes the content of these contracts in a uniform way.

\subsection{A SET OF PROVISIONS PREPARED UNILATERALLY BY ONE PARTY}

The authorship of the contract template is considered irrelevant. A standard contract can be written by the entrepreneur in persona, by a third party or compiled automatically by an electronic system. Thus, the fact that the customer profiling or compilation of contractual provisions is automated, without the actual participation of an entrepreneur, or in a way chosen by him (electronic agents), is irrelevant when assessing the nature of contracts.

The unilateral nature of the standard contract is understood as the lack of influence of the other party on its content. However, personalization can be performed only if at least one of prerequisites of Art. 6 GDPR is fulfilled - typically, if the consumer agreed to profiling in advance. ${ }^{17}$ The modus operandi of personalization mechanisms depends on the entrepreneur, but the amount and content of data processed is a derivative of consumer behaviour. Thus, the consumer, through specific behaviours, can prevent the use of personalization or influence the personalization data through appropriate actions. ${ }^{18}$

In the case of personalized contracts, there are no negotiations between the entrepreneur and the customer. The adjustment of the content takes place before making an offer. The use of personalization mechanisms leads

16 Łętowska, E. (2002) Prawo umów konsumenckich. 2nd ed. Warszawa: Wydawnictwo C.H. Beck, p. 320; Rejdak, M. (2005) Op. cit., p. 127; Bednarek, M. (2013) Op. cit., p. 596; Radwański, Z. and Olejniczak, A. (2018) Zobowiązania: część ogólna. 13th ed. Warszawa: C. H. Beck, p. 144.

17 The issue discussed in: 4. Initiation of the personalization process.

18 When the model of consumers' strategic behaviour is used, the risk of data manipulation skyrockets. See a case of calculating creditworthiness based on the fact that people who buy furniture pads to protect their floors are considered trustworthy debtors. Duhigg, C. (2009) What Does Your Credit-Card Company Know About You? The New York Times Magazine. [online] Available from: http://www.nytimes.com/2009/05/17/magazine/17credit-t.html [Accessed 12 December 2018]. 
to the formation of individual contractual clauses in advance, which excludes the possibility of the other party's influence on their content. There is no room for subsequent modifications in this model. Nevertheless, the content of the offer depends on the individual characteristics of the consumer - it is shaped to correspond with them. The consumer's characteristics and expectations (explicitly or implicitly expressed in the data that is used during personalization process) should, therefore, have a substantial impact on the content of the contract.

Lack of dialogue at the pre-contractual stage may be seen as the effect of using effective tools to adapt the offer to the client's needs. The purpose of personalization is, after all, to enhance the consumer's trust towards the entrepreneur. ${ }^{19}$ The need to negotiate in order to adapt the offer to the consumer's requirements disappears, because it is shaped based on his profile.

The use of personalization mechanisms should lead to the same effect as individual negotiations. However, it should be emphasized that the use of profiling and personalization does not automatically mean individualization of each of the potential clients. These tools allow for shaping marketing practices, including offers, to give the consumer the impression of an individual relationship with the entrepreneur. In the case of segmentation-based personalization, ${ }^{20}$ such an individual relationship does not arise - it is only imitated. In addition, the fact that provisions are individually designed does not automatically mean that they should be qualified as individually negotiated. Unilaterality means there is a lack of negotiation, not of individual approach. ${ }^{21}$

Therefore, the premise of unilaterality should be understood strictly as the lack of dialogue between the parties, and personalized contracts can be considered unilaterally shaped by the entrepreneur.

\footnotetext{
19 Borocz, I. (2015) Clash of Interests - Is Behaviour-Based Price Discrimination in Line with the GDPR. Studia Iuridica Auctoritate Universitatis Pecs Publicata, $153(37)$, p. 42. Use of personalization makes it possible to build trust based on individualisation. Komiak, Sh. and Benbasat, I. (2006) The Effects of Personalization and Familiarity on Trust and Adoption of Recommendation Agents. MIS Quarterly, 30 (4), pp.941-960. However, it should be noted that personalization of certain elements such as price might lead to opposite effects. Furner, Ch. P., Serino, C. M. and Smatt, C. Making it personal: How personalization affects trust over time. [online] Available from: http://ieeexplore.ieee.org/ document/1385576/ pp. 8-9 [Accessed 1 May 2019].

20 Firstly customers are grouped together according to identifiable characteristics (e.g. age, geography, gender, favourite brand) and then the content is adjusted to match each group.

21 Rzetecka-Gil, A. (2011) Kodeks cywilny. Komentarz. Zobowiązania-część ogólna. LEX no 8853, Art. $385^{1}$, point 22 .
} 


\subsection{USED FOR MASS CONTRACTING}

Emphasis is placed on the function of standard terms - they serve the proposer to conclude contracts. However, it is not specified whether these provisions concern only the rights and obligations of the parties in the contract, ${ }^{22}$ or also the norms governing the conduct of the entrepreneur within the scope of his professional activity (personalization, marketing methods, etc.). According to the latter, to fulfil the rules of the incorporation of requirements, the entrepreneur should disclose the personalizing mechanisms to lawfully use them when shaping the agreement. Yet, this interpretation should be rejected, as the application of personalization mechanisms should be seen as part of the process of contract formation, not the contract itself.

The standard contract can be understood as an agreement for an unlimited number of contracts ${ }^{23}$ or which provisions should be applied in at least three legal relationships. ${ }^{24}$ Some scholars argue that the fact that there has been only one contract concluded with the use of a set of terms or that these terms are used sporadically impedes classifying them as standard terms. ${ }^{25}$

However, this means that an important role in shaping the nature of a given statement is then left to luck. If the entrepreneur drafts a standard contract with the purpose of applying it repeatedly, but after concluding one agreement decides not to use it again, then this set of provisions will be considered an individually imposed set of provisions, not standard terms. Therefore, the premise ought to be understood as a set of norms prepared to be used when concluding an unlimited number of contracts with an unlimited number of contractors. It is therefore enough that the standard terms were designed to be used repeatedly - their factual application is irrelevant. $^{26}$

$\overline{22}$ Rejdak, M. (2015) Op. cit., p. 127; Trzaskowski, R. (2018) In: Jacek Gudowski (ed.). Kodeks cywilny. Komentarz. Tom III. Zobowiązania. Część ogólna. Warszawa: Wolters Kluwer, LEX no 10698, Art. 384, point 20.

23 Zachariasiewicz, M. A. (1995) Niektóre problemy prawne związane z korzystaniem z nienormatywnych wzorców umownych. Rejent, 9, p. 122.

24 Zoll, F. (1997) Potrzeba i kierunek nowelizacji kodeksowego ujęcia problematyki wzorców umownych. Biuletyn Rady Legislacyjnej, 1, p. 90.

25 Rejdak, M. (2005) Op. cit., p. 117.

26 (2016) Court of Appeal in Warsaw, VI ACa 1285/15, 9 November. [online] Available from: http://orzeczenia.waw.sa.gov.pl/details/\$N/154500000003003_VI_ACa_001285_2015_Uz_ 2016-11-09_002 [Accessed 11 December 2018]. 
Nevertheless, the fulfilment of this premise in the case of personalized contracts is dubious. There are two possible scenarios: first, segmentation-based personalization - which is the model frequently applied nowadays and second, triggered real-time adjustment. In the case of the segmentation of profilees the same model of contract is applied to all members of a given group. The larger the group is, the more times a particular pattern will be used. In principle, the same pattern is used for mass contracting.

However, the above model constitutes a simplification and may become obsolete with the development of personalization techniques. If personalizing mechanisms are used to generate the contents of contracts, ${ }^{27}$ it becomes possible to compile standard terms for each consumer individually on the basis of data contained in the entrepreneur's system. ${ }^{28}$

Personalization is based on the use of electronic tools that are specific reusable algorithms. Thus, the mass element appears in this case not in reference to a particular set of terms but to the mechanism of its creation. This applies to the consumer's data, the collection of clauses and the code used to compose pattern - thus, although the outcome differs, the mechanism of personalization is common and serves for the mass conclusion of contracts.

As a result, it is not the set of standard terms that is applied for mass contracting, but the mechanism of their creation.

\subsection{SHAPING THE CONTENT OF CONTRACTS IN A UNIFORM WAY}

Personalization can take different forms, manifesting in the manner of concluding the agreement (e.g. bidding, auction), elements related to the form of the offer, its content, time and means of communication or lack thereof. If personalization concerns elements not related to shaping the content of the relationship, which arise as a result of the conclusion of a personalized contract, it will not affect the classification of the contract. Similarly, if the personalization affects only elements individualising the parties or main obligations of the parties (e.g. determination

\footnotetext{
27 On first-degree price discrimination: Acquisti, A., Taylor, C. and Wagman, L. (2016) The Economics of Privacy. Journal of Economic Literature, 52 (2), p. 466.

28 Similar postulates have been already offered by $C$. Busch regarding information duties. Busch, C. (2016) The Future of Pre-contractual Information Duties: From Behavioural Insights to Big Data. In: Christian Twigg-Flesner (ed.). Research Handbook on EU Consumer and Contract Law. Cheltenham, UK, Northampton, MA, USA: Edward Elgar Publishing, pp. 221-241.
} 
of the price), it will be assumed that personalization did not cover standard terms, as these can never include individualising elements. Defining an individual consumer or specifying the subject of the contract will always have the character of an individually negotiated provision. ${ }^{29}$

Uniform shaping of the contract template means that it will define the content of future contracts identically, in isolation from the specifics of a particular contractual relationship. ${ }^{30}$ The aim of using personalizing mechanisms is, however, to introduce individualization. If profiling results in the creation of multi-person groups, a unified pattern can be used within a given group. As long as the personalization creates only the appearance of individualisation, it is reasonable to argue that personalized agreements have uniform content and that they standardize contractual relationships.

The problem arises if entrepreneurs start mixing and changing clauses depending on the occurrence of specific characteristics of the consumer. The number of possible combinations of provisions can vary - theoretically, every consumer might be treated differently. In this case, the thesis that personalized contracts lead to the uniform shaping of the content of contracts will be unjustifiable.

\subsection{HYBRID CHARACTER OF THE PERSONALIZED AGREEMENT - CONCLUSIONS AND RECOMMENDATIONS}

A certain duality of the personalized agreement is to be observed - they have characteristics of both individually negotiated contracts and standard contracts. The content of personalized agreements is shaped by the entrepreneur - the consumer has no real impact on the content of commitment because he cannot negotiate it. At the same time, however, the consumer's features and behaviour have a decisive impact on the content of the offer. The lack of traditional negotiations may be seen as an element indicating the adhesive character of the contract, but it can be argued that negotiations are becoming an anachronism - they are replaced by profiling tools, which are supposed to lead to the same effect as negotiations between the parties.

A personalized offer can be single-use, but it can also be prepared to be leveraged on numerous occasions, depending on the technology used

29 Radwański, Z. (2003) Zobowiązania: część ogólna. 4th ed. Warszawa: C.H. Beck, p. 142.

30 (2011) Court of Appeal in Katowice, V ACa 546/11, 29 November. [online] Available from: https://www.katowice.sa.gov.pl/container/orzeczenia/V_ACa_546-11.pdf

[Accessed 11 December 2018]. 
by the entrepreneur. In the case of personalization through profiling, it is possible to observe unification within a given group due to the fact that personalization leads only to apparent individualization. The development of personalization mechanisms can result in further granularization of personalized contracts - each might be generated separately, for every single customer.

As a result, it is impossible to apply the norms of either of the regimes directly. Due to qualification doubts, as well as the lack of specific normative regulation of personalized agreements, it is necessary to search for the optimal solution, having in regard the aim of the legislator when regulating the relationship between the consumer and the business - that is, the need to diminish the undesired effect of contractual inequality between these parties.

Considering the need to protect the consumer, it would be advisable to allow the per analogiam application of norms regulating adhesive agreements, as this regime provides higher protection then rules on individually negotiated contracts or unilaterally imposed provisions. It sets strict rules on incorporation of standards terms (it shall be delivered to it prior to the conclusion of the contract and, if in an electronic form, it shall be made available to the other party prior to the conclusion of the contract in such a manner that the latter is able to store and retrieve the template in the regular course of actions ${ }^{31}$ ). It impedes positioning the quality of service or product below the average without drawing consumers attention to that particular provision. ${ }^{32}$ Finally, it battles disproportionality within rights and obligations of the parties by implementing general, standardized protection. ${ }^{33}$

\section{PERSONALIZATION PROCESS FROM}

\section{THE PERSPECTIVE OF UNFAIR COMMERCIAL} PRACTICES FRAMEWORK

The UCPD has been implemented into Polish law by the Act on Competition and Consumer Protection and the Act on Counteracting Unfair Market Practices

\footnotetext{
Art. 384 § 1, 4 PCC.

32 Zoll, F. (2012) Problem negatywnego uzgodnienia cech rzeczy sprzedanej - w oczekiwaniu na wspólne europejskie prawo sprzedaży. Transformacje Prawa Prywatnego, 2, pp. 167-174.

33 Rules on exploitation (Art. 388 PCC), unfair terms and unexpected clauses regulation (Art. 3851-4 PCC), Luzak, J. (2017) You too will be judged: erga omnes effect of registered unfair contract terms in Poland. Journal of European Consumer and Market Law, 6 (3), pp. 120-124.
} 
(ACUMP). The latter, in accordance with the implemented directive, provides a general definition of unfair market practice - a practice that is contrary to good morals, interpreted as opposing the requirements of professional diligence ${ }^{34}$ and materially distorts or is likely to materially distort the market behaviour of the average consumer with regard to the product. Therefore, this regulation addresses the issue of the permissibility of the personalization method that leads to a certain result e.g. a personalized marketing technique or a personalized offer.

Though this definition seems broad and irrespective of technology applied, there are certain issues that make protecting consumers from the undue influence of entrepreneurs less effective in the personalized online environment.

It can be doubted whether an individual activity of an entrepreneur e.g. addressing a consumer with an individually tailored offer - can be considered a market practice. This interpretation has been rejected. Market practice means, among other things, a statement or piece of information that could take form of a single action. ${ }^{35}$ The UCPD does not contain any indication that the act or omission on the part of the professional must be recurrent or must concern more than one consumer. ${ }^{36}$

The weakness of the protection lies in the standardization of premises. The point of reference is an average consumer, ${ }^{37}$ yet the personalization uses strategies that correspond with the individual addressee's characteristics. A person with a strong authority bias, heavily influenced by the fear of being excluded, who applied to a certain university, views an advertisement where a person dressed as a dentist presents study according to which $70 \%$ of students from this university have already benefited from the newest teeth-whitening treatment. Personalization opens the possibility for adjusting a marketing technique to a set of particular incentives this person is likely to react to. ${ }^{38}$ Such a combined message is highly persuasive in this specific case, and significantly less effective for

34 Stefanicki, R. (2009) Ustawa o przeciwdziałaniu nieuczciwym praktykom rynkowym. Komentarz. Warszawa: LexisNexis Polska, LEX no 10064, Art. 4, point 1.

35 Polski Zwiazek Firm Deweloperskich v. Prezes UOKiK (2010) SOKiK (Court of Competition and Consumer Protection) 25 March, No XVII Ama 43/09, Dziennik Urzędowy UOKiK, 3, p. 104.

36 Nemzeti Fogyasztóvédelmi Hatóság v. UPC Magyarország Kft. (2015) TSUE. No. C-388/13, § 42.

37 As worded in Art. 2 point 8, Art. 4. 1., Art. 5. 1., Art. 6. 1., Art. 8. 1. ACUMP in accordance with motive 18, Art. 5.2.b., Art. 6.1 and 2, Art. 7.1 and 2, Art. 8 UCPD.

38 Calo, R. (2014) Digital Market Manipulation. The George Washington Law Review, 82, pp. 996, 999, 1010. 
other customers. ${ }^{39}$ Therefore, the practice cannot be considered likely to materially distort the market behaviour of the average consumer. If the point of reference remains standardized, the protection mechanism will fail to cover such individualized practices.

Another issue is drawing a line between sophisticated, persuasive marketing techniques and unfair market practices. Personalization means processing data on consumer, which allows for determining his weaknesses, complexes, fears and behavioural biases. ${ }^{40}$ This allows entrepreneurs to put the consumer under pressure in a manner which strongly limits the consumer's ability to make an informed decision. In certain situations, mechanisms based on persuasion can exert an undue pressure on the person, ${ }^{41}$ which opens the possibility of classifying such behaviour as an aggressive practice. Can personalization significantly impair the consumer's ability to make an autonomous decision - limiting his freedom of choice? Can entrepreneurial practices cause someone to make a contractual decision which they would not have made otherwise? Answering these questions depends primarily on the results of empirical research on consumer behaviour towards personalized content. ${ }^{42}$ In practice, a deep ad casu analysis of the effectiveness of a particular personalization tool would be needed - requiring access to personalization mechanisms, data on users, the results of personalization, user feedback and information on factual customer responses and data how the fair personalization - matching the needs and situations, not abusing weaknesses - influences the consumer's tendency to make certain contractual decisions.

In addition, frequently, personalization means matching pressure to one's weaknesses. The consumer is not misled in regards to the characteristics of the product, nor coerced into concluding an agreement. The entrepreneur manipulates him by providing personalized content, without disclosing information on the personalization

\footnotetext{
39 Wagner, G. and Eidenmüller H. (2019) Down by Algorithms? Siphoning Rents, Exploiting Biases, and Shaping Preferences: Regulating the Dark Side of Personalized Transactions. The University of Chicago Law Review, 86, p. 594.

40 Ibid, pp. 593-594.

${ }_{41}$ Schulze, R. and Schulte-Nölke, H. (2003) Analysis of National Fairness Laws Aimed at Protecting Consumers in Relation to Commercial Practices (Report Commissioned by the European Commission, DG Sanco), p. 37. [online] Available from: https://irias. kuleuven.be/bitstream/123456789/204413/1/unfair_practices_en.pdf [Accessed 12 December 2018].

42 Ibid.
} 
process itself. As a result, only the nudges that amount to undue influence and as such preclude free decision-making or contain misleading information may be considered unfair commercial practices according to the UCPD. ${ }^{43}$ The more conscious the consumers are of the practice, the more substantial nudging could be allowed.

As a rule, the subject to control is a specific practice of the entrepreneur in isolation from his other actions not a set of coordinated practices a customer is faced with. ${ }^{44}$ However, in the online environment, the behaviours of the entrepreneur can be combined, which increases their effectiveness. ${ }^{45}$ Each practice assessed separately might not be influential enough to materially distort the consumer's behaviour, yet, if it is designed to correlate with others, the impact of the whole mechanism grows. An example can be the case of a person fighting obesity and a donut advertisement. Provided that the message about the new promotion of his favourite donuts reaches him at the time when he used to have snack break at work and mentions the nearby bakery, the temptation would be considerably stronger than if the advertisement was not personalized.

Hence, it would be recommended to adopt a broader approach when assessing the character of a practice in question - taking into account also other practices of the entrepreneur and assessing the influence of the practice bundle on a consumer. As well current point of reference being an average consumer, though sufficient in case of segmentation-based personalization, might not maintain its functionality in the era of personalization. However, changes in this regard might not be necessary as here the individual protection mechanisms of defects of consent come into play (especially institution of mistake, fraud and threat).

\section{INITIATION OF THE PERSONALIZATION PROCESS}

The third group of norms is aimed at regulating the acceptability of use of personalization mechanisms - constituting the legal requirements for

43 Brownsword, R. (2018) The E-Commerce Directive, Consumer Transactions, and the Digital Single Market-Questions of Regulatory Fitness, Regulatory Disconnection and Rule Redirection. In: Stefan Grundmann (ed.). European Contract Law in Digital Age. Cambridge, Antwerp, Portland: Intersentia, p. 187.

44 Nevertheless, when assessing whether the market practice is aggressive, all its features and circumstances of placing the product on the market should be considered, in particular time, place, type of a given practice or the intentional use by the entrepreneur of a compulsory location of the consumer or other circumstances which limit the consumer's ability to make an informed decision regarding the contract. See Art. 8.3 ACUMP.

45 Brownsword, R. (2018) Op. cit., pp. 165-172; Calo, R. (2014) Op. cit., pp. 995-1017. 
lawful personalization processes. It is commonly accepted that data protection laws apply to personalized pricing. ${ }^{46}$ Though what justifies the application of the norms of the GDPR is the processing of personal data, up until now, the research focused on one aspect of personalization - price personalization. The same observations can be made in the case of personalization leading to other results. The use of personalization itself might make the entrepreneur subject to the GDPR, regardless of the effect of this process.

The first premise of the application of the GDPR is the processing of personal data. According to Art.4(2) of the GDPR, nearly all the activities which can be exercised over personal data fall within this scope. Therefore, any operation or set of operations which is performed on personal data during personalization or with the objective of personalization, including storing or analysing data, constitute the processing of personal data.

Personal data encompasses any information relating to an identified or identifiable natural person [Art.4(2) GDPR]. There are two main scenarios to consider - a registered consumer case and a non-registered consumer case. In the first, the profilee provides the data knowingly and voluntarily during the registration process. Subsequently, his activities are monitored and this data supplements the information within his profile. As a result, all the information that is gathered on such a profile is considered personal data. The qualification of data processed in the second situation is not that clear. A user that is not registered nor signed-in as a rule will not be identified in a traditional manner. Nevertheless, there are other ways of identifying him each time he accesses the webe.g. a cookie-identifier. The actions he takes in the online environment can be tracked and saved on his unique profile. This method allows for singling out a particular person, therefore the gathered profile data is considered personal data despite the lack of information traditionally used for individualisation (e.g. name, login). ${ }^{47}$ Doubts emerge in the case of information that is not per se connected to the user's identity and is used

\footnotetext{
46 Steppe, R. (2017) Online price discrimination and personal data: A General Data Protection Regulation perspective. Computer Law E Security Review, 33, pp. 768-785; Zuiderveen Borgesius, F.J., Poort, J.P. (2017) Online Price Discrimination and EU Data Privacy Law. Journal of Consumer Policy, 40 (3), p. 356; Borocz, I. (2015) Op. cit., pp. 50-52.

47 Zuiderveen Borgesius, F.J. and Poort, J.P. (2017) Op. cit., p. 357; Article 29. Working Party 2010 Opinion 2/2010 on Online behavioural advertising (WP 171) 22 June 2010; Judgement of 19 October 2016, Breyer, Case C-582/14, ECLI:EU:C:2016:779 regarding a dynamic IP address.
} 
for segmentation purposes - e.g. the fact that the person uses an Apple device. At the moment in which this data is connected to the profile of a particular person, it becomes personal data, as it becomes related to an identified natural person.

Personal data should be processed in accordance with the requirements of the GDPR - that is, inter alias, fairly, lawfully and transparently.

In the case of personalization during the pre-contractual stage in the private sector, there might be three legal grounds for processing personal data: the data subject has given consent (Art. 6a GDPR), processing is necessary for the performance of a contract (Art. 6b GDPR) or there are legitimate interests of the controller involved (Art. 6f GDPR). The doctrine ${ }^{48}$ rejects the two latter grounds. The premise that the data is necessary for the performance of a contract or because of legitimate interests of the entrepreneur is understood narrowly; neither the fact that the processing of this data may maximise the profits of the processor nor the circumstance that the company sees this data as useful while developing its marketing strategies falls within their scope. ${ }^{49}$

Can Art. $6 \mathrm{~b}$ and $6 \mathrm{f}$ constitute grounds for personalization aiming at different results? In the case of personalization that brings about results predominantly beneficial for the business but not bound to the obligation of the entrepreneur (e.g. not sending offers to low-spenders or consumers who often exercise their right to withdraw), as a rule the processing of personalized data should not be seen by Data Protection Authorities as necessary, as there are other ways to maximize profits. In addition, the consumer's interests and rights (especially their right to privacy) override the company's interests in this scenario. ${ }^{50}$

Similarly, processing enables the professional to address individual characteristics of the consumer in a way that is beneficial for both (e.g. no cosmetics containing substance $X$ are advertised to an individual who is allergic to this particular ingredient). However, the fact that such personalization also benefits the consumer is irrelevant ${ }^{51}$ when assessing realization of the premises of Art. 6f. The interests of the consumer should

48 Steppe, R. (2017) Prijsdiscriminatie in het digitale tijdperk: Beschouwingen over de nieuwe algemene verordening gegevensbescherming. In: Matthias E. Storme, Werner F. Helsen (eds.), Innovatie en disruptie in het economisch recht. Antwerpen: Intersentia, pp. 105-149; Zuiderveen Borgesius, F.J. and Poort, J.P. (2017) Op. cit., p. 360. Argumentation formulated in regard to price discrimination.

49 Kuner, C. (2007) European data protection law. Corporate Compliance and Regulation. 2nd ed. Oxford: Oxford University Press, pp. 234-235.

${ }^{50}$ Zuiderveen Borgesius, F.J. and Poort, J.P. (2017) Op. cit., p. 360. 
be taken into account but not as a positive premise allowing for personalization but as a negative one - if there are interests or fundamental rights and freedoms of the data subject which require protection of personal data that override legitimate interests pursued by the controller or by a third party, Art. 6f GDPR cannot constitute grounds for such processing. Art. $6 f$ should not be then interpreted as: if there are interests or fundamental rights and freedoms of the data subject whose protection requires processing of personal data, the controller or the third party is authorized to process this data despite the lack of other legal grounds for processing (e.g. Art. 6d).

The most controversial situation appears when the processing of personal data is beneficial for the entrepreneur but also constitutes an optimal manner of fulfilling legal obligation, e.g. enables the entrepreneur to assess the risk of the other party evading the obligation (e.g. the person is included in the national debtors' register). Here, a legitimate interest of the administrator lies incompliance with the requirement of due diligence when selecting a contractor. The processing of personal data might be considered necessary to achieve the objective resulting from the aforementioned interest - processing data on users is the core instrument that allows for diminishing anonymity within the online environment and reducing transaction risks. However, accepting this argumentation leads to the following conclusion: personalization should be allowed in e-commerce in every case, as it is the best solution for reducing anonymity and enhancing trust online. Consequently, the consumer is practically stripped of the protection granted by GDPR. Therefore, in this scenario, the entrepreneur's interests (to apply the most suited tools to fulfil his legal obligation) should be considered overridden by the interests or fundamental rights and freedoms of the data subject (mainly right to privacy).

Consequently, the only ground for processing personal data for the personalization in the private sector should be the informed consent of the data subject. The data subject should be given clear and comprehensive information about purposes of processing before consenting to be its subject - e.g. before cookies are saved on his device. Furthermore, the purpose cannot be only vaguely or generally described (e.g. "improving

51 Lubasz, D. and Chomiczewski, W. (2018) In: Dominik Lubasz (ed.). RODO. Ogólne rozporzadzenie o ochronie danych. Komentarz. Warszawa: Wolters Kluwer, LEX no 10655, Art. 6 point 7.3. 
user's experience" or "enhancing personalized experience of user"), but must be stated clearly and accurately ${ }^{52}$ so that the data subject can understand the intended results of the personalization (e.g. "personalized pricing" or "inaccessibility of offers not corresponding with profile").

The personalization of offers might fall under the scope of Art. 22 of the GDPR, as it can elicit fully automated decisions with far-reaching effects. $^{53}$ This provision attributes a person the right not to be subject to a decision based solely on automated processing, including profiling, which produces legal effects concerning him or otherwise significantly affects him. Personalized pricing fulfils these premises - (i) an algorithm decides on a price for a particular customer, (ii) in a fully automated manner, (iii) using personal data to evaluate the consumer's willingness to pay. (iv) It affects his legal situation because the determination of a price gives the final shape to his contractual obligation. ${ }^{54}$

The observations made regarding price personalization remain valid for other types of personalization. (i) Personalization mechanisms are designed to result in a decision regarding an individual person, yet their content may differ substantially depending on the functionality of the system (segmentation effect only, choice of manner and time of contact, content or form of offer). (ii) The algorithms used for personalization automate certain processes; in the case of Big Data analysis of consumer data, human intervention is per se unnecessary, except for the instances in which the code is being revised or changed. (iii) The personalization mechanisms work on personal data. (iv) The use of personalization mechanisms, no matter the aim of their particular usage, has a legal effect on the person - it alters his legal situation.

Firstly, the intent of personalization towards the consumer triggers the GDPR general protection. Secondly, it complicates the verification of compliance of the process with the requirements of the UCPD, while enabling the entrepreneur to influence the behaviour of a consumer to an unprecedented degree. Thirdly, it alters the scope of the legitimate expectations of the consumer, as building trust towards an entrepreneur becomes the main goal of personalization. Finally, it may also alter

52 Art. 5.1(b) GDPR.

53 Zuiderveen Borgesius, F.J. and Poort, J.P. (2017) Op. cit., p. 361.

54 Subsumption model presented by: Mendoza, I. and Bygrave, L. A. (2017). The Right Not to Be Subject to Automated Decisions Based on Profiling. [online] Available from: https://ssrn.com/abstract=2964855 [Accessed 12 December 2018]. 
the mechanism of decoding the content of a contract as the information processed within the entrepreneur's systems on the subjective aim of the consumer should be taken into account when assessing the performance of the obligation by the professional.

As a result in each case of personalization, the data subject should be given meaningful information about the logic involved, as well as the significance and the envisaged consequences of such processing for the data subject (Art. 13.2f and 14.2f GDPR). However, the fulfilment of this requirement may be problematic. It can be argued that the specifics of personalization mechanisms constitute company secrets, and even if the company was willing to reveal this information, it might be difficult to explain the reasoning of self-learning tools.

\subsection{WEAKNESSES OF THE CONSENT BASED PROTECTION IN GDPR}

Despite the novelty of the solution proposed within the GDPR, there are certain factors that undermine the functionality of this protective model.

Consent-based protection against use of personalization mechanisms towards a person ${ }^{55}$ constitutes a variation of the protection by information model. ${ }^{56}$ It is believed that with access to the data, the data subject (being the consumer in most cases) is able to make an informed, rational decision even when dealing with a significantly stronger entity. Providing the consumer with easy access to information should be enough to balance information asymmetries and thus prevent this person from being abused or tricked into an unfavourable contract - it is assumed that this person, with all the information at hand, will not agree to exploitation.

However, this protection model has flaws that impair its functionality, especially in the online environment. From the economic analysis of law perspective, the major issues are the cognitive limitations of the addresses of information, ${ }^{57}$ the costs of its processing and the significant disproportion between the costs of reading and understanding information and the benefits of gaining this knowledge. ${ }^{58}$ A person aware of her cognitive

\footnotetext{
55 In this model an informed consent constitutes lawful ground for data processing. Busch, C. (2019) Op. cit., pp. 310-311.

56 Busch, C. (2016) Op. cit., pp. 222-224.

57 Calo, R. (2014) Op. cit., pp. 1000-1001.

58 Mikłaszewicz, P. (2008) Op. cit., pp. 62-63; Luzak, J. (2015) Online Disclosure Rules of the Consumer Rights Directive: Protecting Passive or Active Consumers? Journal of European Consumer and Market Law, 4 (3), p. 82.
} 
limitations is not willing to make an effort which will most likely fail to improve the situation or expand her knowledge. The average consumer has neither the expertise on the subject of the contract, nor the knowledge of the law to allow an accurate interpretation of all provisions in a standard contract. Internet tools enable the consumer to diminish the influence of these factors, as they automate the comparison of content and facilitate the search for important pieces of information. However, they do not compensate for the increasing amount of data that the consumer is exposed to as a consequence of every click online. ${ }^{59}$

The GDPR consent-based protection resulted in a multiplication of the information the consumer is presented with at the pre-contractual stage. From the legislators' perspective, an individual should be given detailed and specific information on the processing of his personal data before consenting to processing - that is, before he can familiarize himself with the content he is looking for. This means that most actions taken by the consumer online will trigger a consent request. Then more information appear - e.g. the pre-contractual information demanded by the consumer rights directive. This inevitably leads to information overload. $^{60}$

This critical point of information overload comes surprisingly fast in the case of online transactions. Behavioural studies show that the above is due to the intensity of the exposure to data, the conviction of the personal irrelevancy of the information presented and that the information is already known (assumption of repeatability of the information within pop-ups of certain kind) and the abundance of distractions within this environment and outside of it (short attention span). ${ }^{61}$

Last but not least, some undesirable entrepreneur behaviour models are observed. The main problem is the "take-it-or-leave-it" approach. The consumer that does not agree to the processing of his personal data is automatically denied access to the website or has to pay for it. The Internet's implied characteristic is the coexistence of numerous sites offering the same content/services and competing for users. This predication loses its accuracy in the case of sales portals or sharing economy portals; these tend to merge

59 Busch, C. (2019) Op. cit., pp. 330-331.

60 Busch, C. (2019) Op. cit., p. 322.

61 Południak-Gierz, K. (2017) From Information Asymmetry to Information Overload Technological Society of Consumers. In: Patrícia Kaplánová (ed.). Contemporary issues of societal development. Novo mesto, pp. 31-47. 
and concentrate the majority of online traffic within a certain market (e.g. Airbnb, Uber, Amazon, Polish Allegro). Therefore, the decision to avoid one portal causes a similar result to the overall resignation from access to a specific Internet market.

\subsection{POSSIBLE ENHANCEMENTS OF GDPR'S CONSENT-BASED PROTECTION MODEL}

Principles present in GDPR (core principles of legitimacy, proportionality and legality as well as limitation purpose) set an adequate benchmark for the data protection regulation. However, in case of personalization within consumer e-commerce, the fact that the legal ground of processing of data is the consent of the data subject might limit GDPR's practical impact. Nevertheless, the effectiveness of the current informed consent-based protection model of GDPR can be increased.

The first, albeit temporary, approach aims at limiting the amount of information the data subject is provided with before the commencement of personalization. It requires empirical research on the reasons consumers fear and reject personalization. According to recent studies, the most problematic issue concerns price discrimination, ${ }^{62}$ yet the matter requires further investigation. The solution might be to expressly inform the consumer only about the typical most unwanted aspects of personalization and provide a way to access extra information.

Another option, though rather practical then legal, would be to let the current regulation operate but encourage the members of the Internet society to "name and shame" ${ }^{163}$ - that is, to investigate which entities processing data are not in line with the requirements of the GDPR, exercise especially user-unfriendly profiling or implement personalization not in order to adjust the offer to the needs and characteristics of the consumers, but to exploit false convictions and trick them into less favourable contracts. ${ }^{64}$

$\overline{62}$ Zuiderveen Borgesius, F.J. and Poort, J.P. (2017) Op. cit.; Borocz, I. (2015) Op. cit., p. 37.

63 This model is based on the assumption that Internet societies have significant self-regulatory potential. Poullet, Y. (2002) How To Regulate Internet: New Paradigms For Internet Governance Self-Regulation: Value And Limits. In: Claire Monville (ed.). Variations sur le droit de la société de l'information. Bruxelles: Bruylant, pp. 84-91. [online] Available from: http://www.crid.be/pdf/public/4656.pdf [Accessed 2 May 2019]; Schultz, T. (2008) Carving up the Internet: Jurisdiction, Legal Orders, and the Private/Public International Law Interfaces. The European Journal of International Law, 19 (4), pp. 829-837.

64 On misperceptions: Bar-Gill, O. (2019) Algorithmic Price Discrimination When Demand Is A Function Of Both Preferences And (Mis)Perceptions. University of Chicago Law Review, 86 (2), pp. 228-232; Calo, R. (2014) Op. cit., pp. 1003-1017. 
It is also worth considering imposing default standards on entities using personalization. $^{65}$ Forbidding or limiting the use of Big Data for personalization (e.g. banning price discrimination) might be equally harmful to consumer interests ${ }^{66}$ so this would require in-depth research on the functioning of personalization mechanisms. Another issue is that if norms are set in legislative procedure they might quickly become outdated, as the development speed of technological and marketing techniques makes it difficult to set technologically insensitive norms. Some solutions might be to link the standards to other values (entrepreneurs should not ask for consent to use data in a way that is against contractual fairness, but simply refrain from doing so), to attribute the responsibility for data processing to the visible entities and to implement privacy-enhancing technology (e.g. a browser's default settings should not allow for identifying its user). Nevertheless, general clauses based protection is not optimal in the case of $\mathrm{B} 2 \mathrm{C}$ relations.

The newest proposition is based on the idea of the personalization of laws regarding personalization. ${ }^{67}$ The matter was investigated in regard to personalized pricing. The use of personalized price caps was proposed, which could diminish the effect of misperception on consumers' willingness-to-pay. ${ }^{68}$ Another option was to personalize information duties based on the use of personalization - the information should precisely name the gains and losses of personalization used by the trader. In the case of personalized pricing, that would be information on the true value of the product towards a particular consumer. ${ }^{69}$ The main weakness of the solution is the lack of incentive for the entrepreneur to eliminate the misperception-based component of the willingness-to-pay. ${ }^{70}$ Secondly, the personalization of law, though alluring, poses a serious threat of uncontrollable free discretion in deciding on the legal rights and obligations of market participants, diminishing legal certainty. ${ }^{71}$

\footnotetext{
65 Busch, C. (2019) Op. cit., pp. 323-324.

66 Bar-Gill, O. (2019) Op. cit., pp. 223, 242.

67 Ibid.

68 Bar-Gill, O. (2019) Op. cit., pp. 223, 243-244.

69 Porat, A. and Strahilevitz, L. J. (2014) Personalizing Default Rules and Disclosure with Big Data. Michigan Law Review, 112, pp. 1417-1421; Bar-Gill, O. (2019) Op. cit., p. 244.

70 Bar-Gill, O. (2019) Op.cit., p. 244.

71 Południak-Gierz, K. (2017) Dangers and benefits of personalisation in Contract Law: big data approach. Queen Mary Law Journal, Special Conference Issue: Autumn, pp. 25-36.
} 


\section{MODERN EU PROTECTIVE MECHANISMS VERSUS TRADITIONAL NATIONAL INSTITUTIONS - EFFICIENCY EVALUATION}

The use of personalization algorithms in shaping offers does not pass unnoticed by legal systems, even in instances when personalization itself in not expressly dealt with in legal provisions. The reaction towards personalization can be observed on different levels: when assessing lawfulness of data processing within entrepreneur's tools, setting the point of reference for a fair process of personalization so that it does not become an unfair market practice and at the stage of interpretation of personalized contract. Theoretically, presented legal framework covers the most obvious issues related to the use of personalization mechanism during shaping an offer. However, the efficiency of these sets of rules differ.

Polish contract law - mostly rules on standard contracts - combats the undesired results of personalization by influencing the content of a contract concluded with the use of personalization mechanisms. These mechanisms are not designed to protect entities from disloyal use of personalization mechanisms but they reduce the contractual imbalance caused by limited autonomy of the weaker party (usually the consumer). It happens regardless of methodology used to force, trick or convince to conclude the agreement of such wording. As a result, they maintain their functionality also in case of personalized agreements.

Provisions of ACUMP as well as GDPR aim at granting ex-ante protection. The mechanism used in ACUMP (prevention of infringement caused by the improper conduct of the entrepreneur) is being supplemented with an information protection mechanism (consent requirement). The tendency to stretch protection towards the pre-contractual stage in EU law demonstrates the preventive approach of the legislator. However these instruments have certain weaknesses that might reduce their effectiveness.

In case of protection granted by provisions on unfair market practices the main issue is standardization of the point of reference. It impedes taking into account subjective peculiarities of a particular case that limit autonomy of this consumer - and the power of personalization is bestowed precisely in addressing these elements. Also, it might not be a singular practice that limits the autonomy of a person but the frequency and correlation between the practices. These features are not adequately addressed by the current 
regulation and therefore, the effectiveness of protection granted within ACUMP in case of personalization mechanism is limited.

In comparison, the newly introduced protective mechanism of GDPR, designed as an answer to big data technology, is founded upon old protective assumptions. As a result, this protection model is burdened with the flaws of the old protection-by-information regime. In conclusion, applicable ex post national protective regulations remain vital for the protection of consumers concluding personalized agreements, as the protection systems offered by the ACUMP and GDPR seem leaky and not adequate in the era of personalized consumer contracts.

\section{LIST OF REFERENCES}

[1] Acquisti, A., Taylor, C. and Wagman, L. (2016) The Economics of Privacy. Journal of Economic Literature, 52 (2).

[2] Act on Competition and Consumer Protection (Dz.U.2018.798 j.t.).

[3] Act on Counteracting Unfair Market Practices (Dz.U.2017.2070 j.t.).

[4] Bar-Gill, O. (2019) Algorithmic Price Discrimination When Demand Is A Function Of Both Preferences And (Mis)Perceptions. University of Chicago Law Review, 86 (2).

[5] Bednarek, M. (2005) Wzorce umów w prawie polskim. Warszawa: Monografie Prawnicze.

[6] Bednarek, M. (2013) Wzorce umów. In: Zbigniew Radwański (ed.). System Prawa Prywatnego. Vol. 5, Ewa Łętowska (ed.). Prawo zobowiazań - czesść ogólna. 2nd ed. Legalis.

[7] Borocz, I. (2015) Clash of Interests - Is Behaviour-Based Price Discrimination in Line with the GDPR. Studia Iuridica Auctoritate Universitatis Pecs Publicata, 153 (37).

[8] Brownsword, R. (2018) The E-Commerce Directive, Consumer Transactions, and the Digital Single Market - Questions of Regulatory Fitness, Regulatory Disconnection and Rule Redirection. In: Stefan Grundmann (ed.). European Contract Law in Digital Age. Cambridge, Antwerp, Portland: Intersentia.

[9] Busch, C. (2016) The Future of Pre-contractual Information Duties: From Behavioural Insights to Big Data. In: Twigg-Flesner C. (ed.). Research Handbook on EU Consumer and Contract Law. Cheltenham, UK, Northampton, MA, USA: Edward Elgar Publishing.

[10] Busch, C. (2019) Implementing Personalized Law: Personalized Disclosures in Consumer Law and Data Privacy Law. The University of Chicago Law Review, 86 (2).

[11] Calo, R. (2014) Digital Market Manipulation. The George Washington Law Review, 82.

[12] Council Directive 93/13/EEC of 5 April 1993 on unfair terms in consumer contracts (OJ L 95, 21.4.1993, p. 29-34). 
[13] Directive 2005/29/EC of 11 May 2005 concerning unfair business-to-consumer commercial practices in the internal market and amending Council Directive 84/450/EEC, Directives 97/7/EC, 98/27/EC and 2002/65/EC of the European Parliament and of the Council and Regulation (EC) No 2006/2004 of the European Parliament and of the Council. Official Journal of the European Union (2005/L 149/22).

[14] Duhigg, C. (2009) What Does Your Credit-Card Company Know About You? Submitted to: The New York Times Magazine. [online] Available from: http://www.nytimes.com/2009/ 05/17/magazine/17credit-t.html [Accessed 12 December 2018].

[15] Furner, Ch. P., Serino, C. M. and Smatt, C. Making it personal: How personalization affects trust over time. [online] Available from: http://ieeexplore.ieee.org/document/ 1385576/ [Accessed 1 May 2019].

[16] Hellwege, P. (2018) Right of Withdrawal in Distance and Off-Premises Contracts. In: Nils Jansen, Reinhard Zimmermann (eds.). Commentaries on European contract laws. Oxford: Oxford University Press.

[17] Hondius, E. (1995) The Reception of Directive on Unfair Terms in Consumer Contracts by Member States. European Review of Private Law, 3.

[18] Judgement of 19 October 2016, Breyer, Case C-582/14, ECLI:EU:C:2016:779.

[19] Judgement of Constitutional Tribunal (8.12.2003), K 3/02, OTK-A 2003/9/99.

[20] Judgement of Court of Appeal in Katowice (29.11.2011) V ACa 546/11. [online] Available from: https://www.katowice.sa.gov.pl/container/orzeczenia/V_ACa_546-11.pdf [Accessed 11 December 2018].

[21] Judgement of Court of Appeal in Warsaw (1.11.2016) VI ACa 1285/15. [online] Available from: http://orzeczenia.waw.sa.gov.pl/details/\$N/154500000003003_VI_ACa_001285_ 2015_Uz_2016-11-09_002 [Accessed 11 December 2018].

[22] Judgement of Polish Supreme Court (20.07.2017) I CSK 704/16, Legalis no 1668805.

[23] Judgement of Polish Supreme Court (26.03.2010) I CSK 444/09 Legalis no 362191.

[24] Judgement of Polish Supreme Court (7.07.2005) V CK 855/04, PUG 2005/10.

[25] Judgement of Polish Supreme Court (1.03.2017) IV CSK 285/16, LEX no 2308321.

[26] Judgement of Polish Supreme Court (5.09.1991) III CZP 75/91, OSNC 1992/5/67.

[27] Komiak, Sh. and Benbasat, I. (2006) The Effects of Personalization and Familiarity on Trust and Adoption of Recommendation Agents. MIS Quarterly, 30 (4).

[28] Kuner, C. (2007) European data protection law. Corporate Compliance and Regulation. 2nd ed. Oxford: Oxford University Press. 
[29] Łętowska, E. (1974) Problematyka ogólnych warunków i wzorów umów w świetle poglądów doktryny obcej. Studia Prawnicze, 3.

[30] Łętowska, E. (2002) Prawo umów konsumenckich. 2nd ed. Warszawa: C.H. Beck.

[31] Łętowska, E. (2004) Nieuczciwe klauzule w prawie umów konsumenckich. Warszawa: C. H. Beck.

[32] Lubasz, D. and Chomiczewski, W. (2018) In: Dominik Lubasz (ed.). RODO. Ogólne rozporzadzenie o ochronie danych. Komentarz. Warszawa: Wolters Kluwer, LEX no 10655.

[33] Luzak, J. (2015) Online Disclosure Rules of the Consumer Rights Directive: Protecting Passive or Active Consumers?. Journal of European Consumer and Market Law, 4 (3).

[34] Luzak, J. (2017) You too will be judged: erga omnes effect of registered unfair contract terms in Poland. Journal of European Consumer and Market Law, 6 (3).

[35] Mendoza, I. and Bygrave, L. A. (2017) The Right Not to Be Subject to Automated Decisions Based on Profiling. [online] Available from: https://ssrn.com/abstract=2964855 [Accessed 12 December 2018].

[36] Mikłaszewicz, P. (2008) Obowiązki informacyjne wumowach zudziałem konsumentów na tle prawa Unii Europejskiej. Warszawa, Kraków: Wolters Kluwer Polska.

[37] Mularski, K. and Radwański, Z. (2019) Zagadnienia ogólne czynności prawnych. In: Zbigniew Radwański (ed.). System prawa prywatnego, 2, Zbigniew Radwański, Andrzej Olejniczak (eds.). Prawo cywilne - część ogólna. 3rd ed. Warszawa: C.H. Beck.

[38] Nemzeti Fogyasztóvédelmi Hatóság v. UPC Magyarország Kft. (2015) TSUE. No. C-388/13.

[39] Polish Civil Code (Dz.U.2018.1025).

[40] Polski Zwiazek Firm Deweloperskich v. Prezes UOKiK. (2010) SOKiK (Court of Competition and Consumer Protection) 25 March, No XVII Ama 43/09, Dziennik Urzędowy UOKiK, 3.

[41] Południak-Gierz, K. (2017) Dangers and benefits of personalisation in Contract Law: big data approach. Queen Mary Law Journal, Special Conference Issue: Autumn.

[42] Południak-Gierz, K. (2017) From Information Asymmetry to Information Overload Technological Society of Consumers. In: Patrícia Kaplánová (ed.). Contemporary issues of societal development. Novo mesto.

[43] Porat, A. and Strahilevitz, L. J. (2014) Personalizing Default Rules and Disclosure with Big Data. Michigan Law Review, 112 (8).

[44] Poullet, Y. (2002) How To Regulate Internet: New Paradigms For Internet Governance Self-Regulation: Value And Limits. In: Claire Monville (ed.). Variations sur le droit de la société de l'information. Bruxelles: Bruylant. 
[45] Pyrzyńska, A. (2019) In: Maciej Gutowski (ed.). Kodeks cywilny. Tom II. Komentarz. Art. 353-626. 2nd ed. Legalis.

[46] Pyziak-Szafnicka, M. (1994) Kilka uwag na temat ochrony przed narzucaniem nieuczciwych warunków umowy. Przegląd Prawa Handlowego, 9.

[47] Radwański, Z. (2003) Zobowiązania: część ogólna. 4th ed. Warszawa: C.H. Beck.

[48] Radwański, Z. and Olejniczak, A. (2018) Zobowiązania: część ogólna. 13th ed. Warszawa: C. H. Beck.

[49] Regulation (EU) 2016/679 of the European Parliament and of the Council of 27 April 2016 on the protection of natural persons with regard to the processing of personal data and on the free movement of such data, and repealing Directive 95/46/EC (General Data Protection Regulation). Official Journal of the European Union (L 119, 4.5.2016).

[50] Rejdak, M. (2005) Definicja terminu „wzorzec umowy konsumenckiej”. Ruch Prawniczy, Ekonomiczny i Socjologiczny, LXVII (3).

[51] Rzetecka-Gil, A. (2011) Kodeks cywilny. Komentarz. Zobowiąania- część ogólna. LEX no 8853 .

[52] Schultz, T. (2008) Carving up the Internet: Jurisdiction, Legal Orders, and the Private/ Public International Law Interfaces. The European Journal of International Law, 19 (4).

[53] Schulze, R. and Schulte-Nölke, H. (2003) Analysis of National Fairness Laws Aimed at Protecting Consumers in Relation to Commercial Practices (Report Commissioned by the European Commission, DG Sanco), 37. [online] Available from: https://lirias. kuleuven.be/bitstream/123456789/204413/1/unfair_practices_en.pdf [Accessed 12 December 2018].

[54] Schulze, R. and Zoll, F. (2018) European Contract Law. 2nd ed. München: C. H. Beck; Oxford: Hart; Baden-Baden: Nomos.

[55] Stefanicki, R. (2009) Ustawa o przeciwdziałaniu nieuczciwym praktykom rynkowym. Komentarz. Warszawa: LexisNexis Polska.

[56] Steppe, R. (2017) Online price discrimination and personal data: A General Data Protection Regulation perspective. Computer Law \& Security Review, 33.

[57] Steppe, R. (2017) Prijsdiscriminatie in het digitale tijdperk: Beschouwingen over de nieuwe algemene verordening gegevensbescherming. In: Matthias E. Storme, Werner F. Helsen (eds.). Innovatie en disruptie in het economisch recht. Antwerpen: Intersentia.

[58] Trzaskowski, R. (2018) In: Jacek Gudowski (ed.). Kodeks cywilny. Komentarz. Tom III. Zobowiązania. Część ogólna. Warszawa: Wolters Kluwer, LEX no 10698. 
[59] Twigg-Flesner C. (2010) In: Hans-W. Micklitz, Jules Stuyck and Evelyne Terryn (eds.). Cases, materials and Text on Consumer Law. Oxford, Portland, Oregon: Hart Publishing.

[60] Wagner, G. and Eidenmüller H. (2019) Down by Algorithms? Siphoning Rents, Exploiting Biases, and Shaping Preferences: Regulating the Dark Side of Personalized Transactions. The University of Chicago Law Review, 86 (2).

[61] Zachariasiewicz, M. A. (1995) Niektóre problemy prawne związane z korzystaniem z nienormatywnych wzorców umownych. Rejent, 9.

[62] Zoll, F. (1997) Potrzeba i kierunek nowelizacji kodeksowego ujęcia problematyki wzorców umownych. Biuletyn Rady Legislacyjnej, 1.

[63] Zoll, F. (2012) Problem negatywnego uzgodnienia cech rzeczy sprzedanejw oczekiwaniu na wspólne europejskie prawo sprzedaży. Transformacje Prawa Prywatnego, 2.

[64] Zoll, F. (2018) Rękojmia. Odpowiedzialność sprzedawcy. Warszawa: Wydawnictwo C. H. Beck.

[65] Zuiderveen Borgesius, F.J. and Poort, J.P. (2017) Online Price Discrimination and EU Data Privacy Law. Journal of Consumer Policy, 40 (3). 